\title{
Optimization of 3-Hydroxy-5-(2,6-dichlorophenyl)-2- mercaptocyclohex-2-enones as Potent Inhibitors of Human Lactate Dehydrogenase
}

\begin{abstract}
Sharada Labadie ${ }^{\mathrm{a}}$, Peter S. Dragovich ${ }^{\mathrm{a}}$, Jinhua Chen ${ }^{\mathrm{b}}$, Benjamin P. Fauber ${ }^{\mathrm{a}}$, Jason Boggs ${ }^{a}$, Laura B. Corson ${ }^{a}$, Charles Z. Ding ${ }^{b}$, Charles Eigenbrot ${ }^{a}$, HongXiu Ge $^{b}$, Qunh $\mathrm{Ho}^{\mathrm{b}}$, Kwong Wah Lai ${ }^{\mathrm{b}}$, Shuguang Ma ${ }^{\mathrm{a}}$, Shiva Malek ${ }^{\mathrm{a}}$, David Peterson ${ }^{\mathrm{a}}$, Hans E. Purkey $^{a}$, Kirk Robarge ${ }^{a}$, Laurent Salphati ${ }^{a}$, Steven Sideris ${ }^{a}$, Mark Ultsch ${ }^{a}$, Erica VanderPorten $^{\mathrm{a}}$, BinQing Wei ${ }^{\mathrm{a}}$, Qing Xu ${ }^{\mathrm{b}}$, Ivana Yen ${ }^{\mathrm{a}}$, Qin Yue ${ }^{\mathrm{a}}$, Huihui Zhang ${ }^{\mathrm{b}}$, Xuying Zhang $^{\mathrm{b}}$, Aihe Zhou $^{\mathrm{a}}$

aGenentech, Inc., 1 DNA Way, South San Francisco, California 94080, USA

bWuXi AppTec Co., Ltd. 288 Fute Zhong Road, Waigaoqiao Free Trade Zone, Shanghai 200131, P. R. China.
\end{abstract}


Tumor cells exhibit altered glucose metabolism compared to normal cells. ${ }^{1}$ They often rely on glycolysis for energy generation in contrast to more efficient mitochondrial tricarboxylic acid (TCA) cycle utilized by healthy cells. ${ }^{2}$ This dependency on glycolysis occurs even in the presence of normal oxygen concentrations. ${ }^{3}$ Lactate dehydrogenase A (LDHA) plays a critical role by catalyzing the conversion of pyruvate to lactate in the last step of the process. ${ }^{4}$ Over-expression of LDHA is detected in many types of cancer cells ${ }^{5}$ and shRNA-mediated LDHA knock-down results in significant inhibition of tumor growth in glycolytically dependent cancer cell lines. ${ }^{6}$ Moreover, humans deficient in LDHA show only mild phenotype suggesting that inhibition of the enzyme will not lead to unwanted toxicities. ${ }^{4,7}$ Collectively, these facts suggest that the selective inhibition of LDHA would provide new therapeutic potential in cancer treatment.

A number of LDHA inhibitors have recently been disclosed (Figure 1, 1-3). ${ }^{8-12}$ Optimization of high throughput screening hits (Figure 1, 4-6) by our group have also been reported. ${ }^{13-15}$ To date, low enzyme potency and poor physiochemical properties have resulted in poor cellular potency. ${ }^{15-17}$ In the case of 3-hydroxycyclohex-2-enone series 6 , containing two lipophilic phenyl rings and an acidic 1,3-dicarbonyl moiety, the lack of cell potency ${ }^{15}$ was ascribed to a high cell-shift associated with the lipophilic acidic template. ${ }^{18}$ To overcome the cell shift associated with these templates without altering the acidity of the molecule, further improvement in biochemical potency was required relative to previously disclosed ${ }^{15}$ inhibitors $6 \mathbf{a}$ and $\mathbf{6 b}$. Herein, we describe the optimization and evaluation of 3-hydroxycyclohex-2-enone series 6 in biochemical and related cellular assays. 
Distinct binding pockets observed in the crystal structure of 3-hydroxy-2-(2chlorophenylthio)-5-(2,6-dichlorophenyl)cyclohex-2-enone, $6 \mathbf{b}$, bound to $\mathrm{LDHA}^{15}$ provided possible functionalization strategies to further enhance the biochemical potency (Figure 2). First, the pocket near the nicotinamide adenine dinucleotide (NADH) binding site contained unoccupied space encompassed by the flexible 100's loop. Favorable interactions with the polar side-chains of the residues R98, Q99, Q100 and E103 of the 100's loop might therefore be realized by functionalization (Figure 1) of the phenyl ring A at C-3 and C-4. The substituents at C-3 might also point inward toward the NADH and make interactions with the functionalities as observed earlier. ${ }^{14}$ Secondly, the C-5' position of the phenyl ring B was in close proximity to the acidic sidechain and backbone NH of the D194 residue of LDHA. Previous SAR exploration from our group showed that the substitution at this position was tolerated ${ }^{15}$ and additional favorable interactions with the protein could be obtained. ${ }^{13}$ This indicated that incorporation of $\mathrm{H}$-bond acceptor/donor moieties at $\mathrm{C}-5$ ' of the ring $\mathrm{B}$ might afford more favorable interactions with LDHA. These structural features collectively suggested that functionalization of $\mathrm{C}-3$ and $\mathrm{C}-4$ of the phenyl ring $\mathrm{A}$ and $\mathrm{C}-5^{\prime}$ of the phenyl ring $\mathrm{B}$ present in molecule, such as $\mathbf{6 b}$, were reasonable strategies to enhance biochemical potency.

Accordingly, several $\mathbf{6 b}$ analogs containing various $\mathrm{H}$-bond donor/acceptor functionalities were evaluated for their LDHA enzyme potencies (Table 1). In comparison to $\mathbf{6 b}$, the $\mathrm{C}-3 \mathrm{~N}$-linked morpholine analog (7) showed a modest four-fold gain in enzyme potency. However, a reduction in potency was observed for the compound with $\mathrm{N}$-linked morpholine at C-4 (8). We then directed our focus towards 
further exploration of $\mathrm{C}-3$ modifications of the phenyl ring A. N-Linked piperazine analogs (9-12) displayed biochemical potencies comparable to 7 . Compounds 13 and 14, substituted with 4-aminotetrahydropyran and isopropyloxy moieties, respectively, showed 15- and 10-fold improvement relative to $\mathbf{6 b}$. We then explored a few C-linked analogs. Compounds containing phenyl (15), 2-chlorophenyl (16) and heteroaryls (1719) in this position of the molecule displayed similar potencies except for the pyrimidine analog 19.

In order to understand the gain in potency from this exploration, a co-crystal structure of a representative molecule, 13, bound to LDHA (Figure 3a) was obtained. ${ }^{19}$ As expected, the inhibitor was bound in the substrate binding site and the neighboring side-chains of residues R168, $\mathrm{H} 192$ and $\mathrm{N} 137$ were within the $\mathrm{H}$-bond distance from the 1,3-dicarbonyl portion of the ligand. The 2, 6-dichlorophenyl ring A was positioned in the equatorial orientation as observed in the crystal structure of $6 \mathbf{b} .{ }^{15}$ Nicotinamide adenine dinucleotide (NADH) co-factor was also present in the complex. The 4aminotetrahydropyranyl group on the ligand appeared solvent exposed and was not pointed inward toward NADH. ${ }^{14}$ Some residues of the 100 's loop were disordered due to crystal packing contacts. Overlay of the X-ray crystal structures of $\mathbf{6 b}$ and $\mathbf{1 3}$ (Figure $3 \mathrm{~b}$ ) revealed that a portion of the 100's loop was considerably closer to the phenyl ring $A$ in 13 compared to the phenyl ring $A$ in the crystal structure of $6 \mathbf{b}$. However, the polar moieties on the side-chains of the 100's loop residues were not in close proximity to make favorable interactions with the 4-aminotetrahydropyranyl group of the ligand $\mathbf{1 3 .}$ The disorderliness and mobility of the 100's loop made it difficult to ascertain 
interactions that may be responsible for potency enhancement for this molecule. We then directed our efforts towards functionalization of $\mathrm{C}-5^{\prime}$ of the aryl ring $\mathrm{B}$.

To obtain interactions with the acid side-chain and backbone NH of D194, as discussed earlier, a new set of compounds with hydrogen-bond donor/acceptor moieties at $\mathrm{C}-5^{\prime}$ of the phenyl ring $\mathrm{B}$ were synthesized and evaluated in biochemical assay (Table 2, 20-32). Compounds with the hydroxyl, methoxy, amino and methyamino groups at C$5(\mathbf{2 0 - 2 3})$ exhibited a modest potency gain relative to $6 \mathbf{b}$. Compound containing carboxylic $\operatorname{acid}^{20}(\mathbf{2 4})$ and amides (25-27) were weaker than the corresponding carboxylic acid esters $^{20}(\mathbf{2 8 - 3 2})$. Among the esters, the (R)-2-phenyethyl ester $\mathbf{3 1}$ was the most potent analog with a 145 -fold improvement in biochemical potency over $6 \mathbf{b}$. This dramatic improvement in potency for $\mathbf{3 1}$ was possibly due to the $\mathrm{H}$-bond interaction between the ester moiety and the backbone $\mathrm{NH}$ of D194 and additional favorable interaction between the phenyl ring and the side-chain of the residue encompassing the binding pocket (see below).

Encouraged by these results, we envisioned that incorporation of functionalities on both rings $A$ and $B$ might produce synergistic effects and provide an inhibitor with greatly improved biochemical potency. Therefore, compounds with substituents at both the $C-3$ of ring $A$ and the $C-5$ ' of ring $B$ were investigated (Table 3, 33-39). The isopropyloxy substituents at C-3 of ring A was selected to test this hypothesis because of the ease of synthesis and the potency improvement with this was comparable to the other groups tested (Table 1). This moiety was combined with hydroxyl and methoxy on C-5' of ring B. These combinations improved enzyme potency only 3-fold over 14 (Table 1). A slight improvement in enzyme potency was observed when the $\mathrm{C}-2$ ' $\mathrm{Cl}$ was 
replaced by $\mathrm{CN}$ providing inhibitor 35 . Other combinations, 4-pyridyl at C-3 and methoxy at C-5 (37), phenyl at C-3 and ethyl acetic acid ester at C-5 (38) and 4aminotetrahydropyranyl group at C-3 and methoxy at C-5 (39) showed only modest potency improvement relative to the mono-substituted analogs. Generally, compounds with substituents both at $\mathrm{C}-3$ of the phenyl ring $A$ and the $C-5$ of the phenyl ring $B$ were more potent than the compounds with substituent on only one of the rings. However, the dramatic synergistic effect was not realized.

A subset of the potent analogs was profiled in a panel of in vitro DMPK assays and against structurally related dehydrogenases. As shown in Table 4, the tested compounds displayed good solubility in $\mathrm{pH} 7.4$ buffered aqueous solutions and low to moderate MDCK permeability. The inhibitors exhibited very high protein binding in plasma from humans. All tested compounds displayed low stability in human liver microsomes because of high cLogPs. ${ }^{21}$ The most potent analog 31 was stable in human plasma and unstable in mouse plasma $(72 \%$ of parent remained after $1 \mathrm{hr}$ in mouse plasma at $37^{\circ} \mathrm{C}$ ). The inhibitors were, typically, 4-10 fold selective for LDHA over LDHB isoform except for the analog 31 which displayed similar potency for both LDHA and LDHB, The inhibitors were inactive $\left(\mathrm{IC}_{50}=>10 \mu \mathrm{M}\right)$ against related malate dehydrogenase $1(\mathrm{MDH} 1)$ and malate dehydrogenase $2(\mathrm{MDH} 2)$ enzymes.

A few potent analogs were tested in MIA PaCa2 cells to assess their ability to inhibit lactate production. ${ }^{22}$ All tested compounds were inactive under normal serum conditions (10\% fetal bovine serum) at inhibitor concentrations of up to $10 \mu \mathrm{M}$. The reasons for lack of cell potency for these inhibitors are unknown but it could be 
potentially due to high protein binding and the high cell-shift associated with the lipophilic acidic templates ${ }^{18}$ and high intracellular LDHA concentration. ${ }^{17}$

A co-crystal structure of the most potent analog $\mathbf{3 1}$ bound to LDHA was obtained to understand the considerable improvement in enzyme potency over $\mathbf{6 b}$ (Figure 4). The inhibitor was bound in the substrate binding pocket similar to that observed for compounds $\mathbf{6 b}$ and $\mathbf{1 3}$. The usually mobile and disordered R105 was well ordered in this complex and the guanidinium moiety of the side-chain was within the $\mathrm{H}$-bond distance $(2.6 \AA)$ from the acid side-chain of D194. ${ }^{19,23}$ This interaction positioned the guanidinium moiety in close proximity to the phenyl ring of the ester at C-5' of $\mathbf{3 1}$ enabling favorable partial $\pi$-cation interaction. ${ }^{24}$ In addition, the carbonyl of the ester moiety was within the $\mathrm{H}$-bond distance $(2.8 \AA)$ from the backbone $\mathrm{NH}$ of $\mathrm{D} 194$. We believe, these two additional favorable interactions with the protein were responsible for the observed gain in potency for the inhibitor 31 .

Syntheses ${ }^{25}$ of 3-hydroxy-2-(2-chlorophenylthio)-5-(2,6-dichlorophenyl)cyclohex2-enone analogs with substitutions on ring $A$ are described in Scheme 1a-c. Deprotonation of 1-bromo-2,4-dichlorobenzene with LDA followed by DMF quench provided the intermediate aldehyde $\mathbf{4 0}$. The aldehyde was converted to $\mathbf{4 1}$ as previously described. ${ }^{15}$ Treatment of $\mathbf{4 1}$ with the 1,2-bis(2-chlorophenyl)disulfane in the presence of potassium carbonate formed $\mathbf{4 2}$. Coupling of $\mathbf{4 2}$ with various secondary amines in the presence of $\mathrm{Pd}_{2}(\mathrm{dba})_{3}$, Xanthphos and cesium carbonate in toluene afforded the amine substituted analogs 7, 9-11 and 13. Deacetylation of 11 under basic conditions yielded 12. Compound 8 was prepared, in a similar fashion to $\mathbf{7}$, starting from $3,5-$ dichlorobromobenzene. Alkylation of 2,4-dichlorophenol with 2-iodopropane produced 
43. Deprotonation of $\mathbf{4 3}$ with $\mathrm{n}-\mathrm{BuLi}$ in hexanes at $-78^{\circ} \mathrm{C}$ and subsequent DMF quench produced the aldehyde $\mathbf{4 4}$ which was converted to $\mathbf{1 4}$ via $\mathbf{4 5}$ as previously described. ${ }^{15}$ Compounds 15-19 were obtained by Suzuki couplings between 42 and boronic acids in the presence of a palladium catalyst.

The compounds with substitutions on the ring B were synthesized as described in Scheme 2. 5-(2,6-Dichlorophenyl)cyclohexane-1,3-dione $46^{15}$ was treated with various thiols, $\mathbf{4 7 a - d}$ and $\mathbf{4 7 f ^ { 2 6 , 2 7 }}$ in the presence of potassium carbonate in acetonitrile to generate compounds $\mathbf{2 0 - 2 4}$. The carboxylic acid 24 was converted to esters and amides (25-32) using either Mitsunobu or HATU coupling conditions.

Scheme 3 describes the synthesis of compounds with substitutions on both rings A and B. Treatment of the intermediate 45 with the thiols $47 a, b, g$ and $h$ provided 33-36. Suzuki coupling on the intermediate $\mathbf{4 1}$ and subsequent treatment of the product $\mathbf{4 8}$ with thiols $47 a$ and 47 e provided compounds 37 and $\mathbf{3 8}$, respectively. Intermediate 41 was converted to 39 via the intermediate 49 .

In summary, structure based design strategies were applied to obtain analogs with considerable improvement in biochemical potency relative to $\mathbf{6 b}$. These inhibitors were substrate competitive and were typically selective for LDHA over LDHB and other structurally related malate dehydrogenases, $\mathrm{MDH} 1$ and $\mathrm{MDH} 2$. A co-crystal structure of the most potent inhibitor $\mathbf{3 1}$ revealed that the carbonyl and the phenyl group of the ester moiety in $\mathbf{3 1}$ were in close proximity to allow $\mathrm{H}$-bond and partial $\mathrm{m}$-cation interactions, respectively, with the protein. Because of the flexibility of the 100's loop, it was difficult to efficiently fill the binding pocket. In addition, the 100's loop was very disordered near 
the inhibitor binding site, perhaps arising from the crystal packing interactions. Therefore, in some cases, interactions that may be responsible for affinity enhancement could not be observed in the crystal structure. Additional efforts to identify inhibitors, in the related scaffold, with improved ability to inhibit LDHA in cell-culture experiments were undertaken and will be reported in due course.

\section{Acknowledgements}

We thank Drs. Krista Bowman and Jiansheng Wu and their respective Genentech research groups for performing protein expression and purification activities. We also thank the Discovery Chemistry Small Molecule analytical group for their support and Dr. Peter Jackson for many helpful discussions regarding LDHA. We thank Crystallographic Consulting, LLC for diffraction data collection. We acknowledge the use of synchrotron X-ray sources at the Advanced Light Source and the Stanford Synchrotron Radiation Lightsource supported by the Department of Energy's Office of Science under contracts DE-AC02-05CH11231 and DE-AC02-76SF00515, respectively.

\section{References}

1. Galluzzi, L.; Kepp, O.; Vander Heiden, M. G.; Kroemer, G. Nat. Rev. Drug Discov. 2013, 12, 829 . 
2. (a) Vander Heiden, M. G.; Cantley, L. C.; Thompson, C. B. Science 2009, 324, 1029.

(b) Hsu, P. P.; Sabatini, D. M. Cell 2008, 134, 703.

3. (a) Warburg, O. Science 1956, 123, 309. (b) Bensinger, S. J.; Christofk, H. R.

Semin. Cell Dev. Biol. 2012, 23, 352. (c) Koppenol, W. H.; Bounds, P. L.; Dang, C. V. Nat. Rev. Cancer 2011, 11, 325.

4. Granchi, C.; Bertini, S.; Macchia, M.; Minutolo, F. Curr. Med. Chem. 2010, 17, 672.

5. (a) Balinsky, D.; Platz, C. E.; Lewis, J. W. Cancer Res. 1983, 43, 5895. (b) Goldman,

R. D.; Kaplan, N. O. Cancer Res. 1964, 24, 389.

6. Fantin, V. R.; St-Pierre, J.; Leder, P. Cancer Cell 2006, 9, 425.

7. (a) Kanno, T.; Sudo, K.; Maekawa, M.; Nishimura, Y.; Ukita, M.; Fukutake, K.; Clinica Chimica Acta 1988, 173, 89. (b) Kanno, T.; Sudo, K.; Takeuchi, I.; Kanda, S.; Honda, N.; Nishimura, Y.; Oyama, K. Clinica Chimica Acta 1980, 108, 267.

8. Le, A.; Cooper, C. R.; Gouw, A. M.; Dinavahi, R.; Maitra, A.; Deck, L. M.; Royer, R. E.; Vander Jagt, D. L.; Semenza, G. L.; Dang, C. V. Proc. Natl. Acad. Sci. 2010, 107, 2037.

9. Kohlmann, A.; Zech, S. G.; Li, F.; Zhou, T.; Squillace, R. M.; Commodore, L.;

Greenfield, M. T.; Lu, X.; Miller, D. P.; Huang, W.-S.; Qi, J.; Thomas, R. M.; Wang, Y.; Zhang, S.; Dodd, R.; Liu, S.; Xu, R.; Xu, Y.; Miret, J. J.; Rivera, V.; Clarckson, T.;

Shakespeare, W. C.; Zhu, X.; Dalgarno, D. C. J. Med. Chem. 2013, 56, 1023.

10. Ward, R. A.; Brassington, C.; Breeze, A. L.; Caputo, A.; Critchlow, S.; Davies, G.; Goodwin, L.; Hassall, G.; Greenwood, R.; Holdgate, G. A.; Mrosek, M.; Norman, R. A.; 
Pearson, S.; Tart, J.; Tucker, J. A.; Vogtherr, M.; Whittaker, D.; Wingfield, J.; Winter, J.; Hudson, K. J. Med. Chem. 2012, 55, 3285.

11. (a) Billiard, J.; Annan, R.; Ariazi, J.; Briand, J.; Brown, K.; Campobasso, N.;

Chakravorty, S. J.; Chai, D.; Colón, M.; Davenport, E.; Dennison, J. B.; Dodson, C. S.; Gaul, N. J.; Gilbert, S.; Jurewicz, A. J.; Lu, H.; McNulty, D.; McSurdy-Freed, J.; Miller, L.; Nurse, K.; Nuthulaganti, P. R.; Quinn, C.; Schneck, J. L.; Scott, G. F.; Shaw, T. N.; Sherk, C.; Smallwood, A. M.; Sweitzer, S.; Villa, J. P.; Waitt, G.; Wooster, P. F.; Duffy, K. J. American Association for Cancer Research 104th Annual Meeting, Washington, DC, April 6-10, 2013, Book of Abstracts. (b) Chai, D.; Colon, M; Dodson, C.; Duffy, K. J.; Shaw, A. N. WO2012/061557.

12. (a) Granchi, C.; Roy, S.; Giacomelli, C.; Macchia, M.; Tuccinardi, T.; Martinelli, A.; Lanza, M.; Betti, L.; Gianniccini, G.; Lucacchini, A.; Funel, N.; León, L. G.; Giovannetti, E.; Peters, G. J.; Palchaudhuri, R.; Calvaresi, E. C.; Hergenrother, P. J.; Minutolo, F. J. Med. Chem. 2011, 54, 1599. (b) Granchi, C.; Roy, S.; De Simone, A.; Salvetti, I.;

Tuccinardi, T.; Martinelli, A.; Macchia, M.; Lanza, M.; Betti, L.; Gianniccini, G.; Lucacchini, A.; Giovannetti, E.; Sciarrillo, R.; Peters, G. J.; Minutolo, F. Eur. J. Med. Chem. 2011, 46, 5398.

13. Dragovich, P. S.; Fauber, B. P.; Corson, L. B.; Ding, C. Z.; Eigenbrot, C.; Ge, H.; Giannetti, A. M.; Hunsaker, T.; Labadie, S.; Liu, Y.; Malek, S.; Pan, B.; Peterson, D.; Pitts, K.; Purkey, H. E.; Sideris, S.; Ultsch, M.; VanderPorten, E.; Wei, B.; Xu, Q.; Yen, I.; Yue, Q.; Zhang, H.; Zhang, X. Bioorg. Med. Chem. Lett. 2013, 23, 3186. 
14. Fauber, B. P.; Dragovich, P. S.; Chen, J.; Corson, L. B.; Ding, C. Z.; Eigenbrot, C.; Giannetti, A. M.; Hunsaker, T.; Labadie, S.; Liu, Y.; Liu, Y. c.; Malek, S.; Peterson, D.; Pitts, K.; Sideris, S.; Ultsch, M.; Vander Porten, E.; Wang, J.; Wei, B. Q.; Yen, I.; Yue. Q. Bioorg. Med. Chem. Lett. 2013, 23, 5533.

15. Dragovich, P. S.; Fauber, B. P.; Boggs, J.; Corson, L. B.; Ding, C. Z.; Eigenbrot, C.; Ge, H.; Giannetti, A. M.; Ho, Q.; Hunsaker, T.; Labadie, S.; Liu, Y.; Ma, S.; Malek, S.; Pan, B.; Peterson, D.; Pitts, K.; Purkey, H. E.; Robarge, K.; Salphati, L.; Sideris, S.; Ultsch, M.; VanderPorten, E.; Wei, B.; Xu, Q.; Yen, I.; Yue, Q.; Zhang, H.; Zhang, X.;

Zhou, A. Bioorg. Med. Chem. Lett. 2014, 24, 3764.

16. Xie, H.; Hanai, J.-H.; Ren, J.-G.; Kats, L.; Burgess, K.; Bhargava, P.; Signoretti, S.; Billiard, J.; Duffy, K. J.; Grant, A.; Wang, X.; Lorkiewicz, P. K.; Schatzman, S.;

Bousamra II, M.; Lane, A. N.; Higashi, R. M.; Teresa W.M.; Fan, T. W. M.; Pandolfi, P. P.; Sukhatme, V. P.; Seth, P. Cell Metab. 2014, 19, 1.

17. Billiard, J.; Dennison, J. B.; Briand, J.; Annan, R. S.; Chai, D.; Colón, M.; Dodson, C. S.; Gilbert, S. A.; Greshock, J.; Jing, J.; Lu, H.; McSurdy-Freed, J., E.; Orband-Miller, L. A.; Mills, G. B.; Quinn, C. J.; Schneck, J. L.; Scott, G. F.; Shaw, A. N.; Waitt, G. M.; Wooster, R. F.; Duffy, K. J. Cancer and Metab., 2013, 1, 19.

18. For related dicarbonyl-containing compounds as inhibitors of HIV protease and HCV NS5B polymerase, see: (a) Li, H.; Tatlock, J.; Linton, A.; Gonzalez, J.; Borchardt, A.; Dragovich, P.; Jewell, T.; Zhou, R.; Blazel, J.; Parge, H.; Love, R.; Hickey, M.; Doan, C.; Shi, S.; Duggal, R.; Lewis, C.; Fuhrman, S. Bioorg. Med. Chem. Lett. 2006, 16, 4834.

(b) Vara Prasad, J. V. N.; Boyer, F. E.; Domagala, J. M.; Ellsworth, E. L.; Gajda, C.; 
Hamilton, H. W.; Hagen, S. E.; Markoski, L. J.; Steinbaugh, B. A.; Tait, B. D.; Humblet, C.; Lunney, E. A.; Pavlovsky, A.; Rubin, J. R.; Ferguson, D.; Graham, N.; Holler, T.; Hupe, D.; Nouhan, C.; Tummino, P. J.; Urumov, A.; Zeikus, E.; Zeikus, G.; Gracheck, S. J.; Saunders, J. M.; VanderRoest, S.; Brodfuehrer, J.; Iyer, K.; Sinz, M.; Gulnik, S. V.; Erickson, J. W. Bioorg. Med. Chem. 1999, 7, 2775.

19. Most procedures to produce and crystallize LDHA/inhibitor complex crystals were as described in ref. 15. LDHA crystals in space group P2(1) were grown by vapor diffusion at $18{ }^{\circ} \mathrm{C}$ using a $50: 50$ mixture of protein stock $(10 \mathrm{mg} / \mathrm{mL})$ and reservoir $(20 \%(\mathrm{w} / \mathrm{v})$ PEG 3350, 0.2M sodium malonate pH 7.0, 2mM NADH). Inhibitors were incorporated by placing crystals in a solution lacking malonate ion (30\% (w/v)PEG 3350, 0.1M HEPES $\mathrm{pH} 7.2,1 \mathrm{mM} \mathrm{NADH}$ ) made $5 \mathrm{mM}$ in inhibitor using a $50 \mathrm{mM}$ DMSO stock solution and waiting 5 - 7 days. See Supplementary Material and deposited pdb file for additional structural details.

20. The benzoic acid $(R=\mathrm{COOH})$ and the corresponding methyl ester $(R=\mathrm{COOMe})$ analogs were inactive against $\mathrm{LDHA}\left(\mathrm{IC}_{50}=>4 \mu \mathrm{M}\right.$, data not shown). The required thiol was prepared according to Godt, H. C.; Wann, R. E. J. Org. Chem.; 1961, 26, 4047.

21. The partition coefficient (cLogP) was calculated with internal software using the VolSurf approach. For additional details, see: Cruciani, G.; Crivori, P.; Carrupt, P.-A.; Testa, B. J. Mol. Struc.-Theochem. 2000, 503, 17.

22. See supplementary material for experimental details.

23. Two of the four protomers in the co-crystal complex with LDHA of compound $\mathbf{3 1}$ showed well-ordered R105. 
24. Paulini, R.; Müller, K.; Diederich, F. Angew. Chem. Int. Ed. 2005, 44, 1788.

25. Compounds were purified by rHPLC and analyzed by LC/MS. All compounds were of $>95 \%$ purity.

26. See supplimentary material for the scheme describing preparation of various thiols.

27. (a) Itoh, T.; Mase, T. Org. Lett. 2004, 6, 4587. (b) Godt, H. C.; Wann, R. E. J. Org. Chem. 1966, 26, 4047.

28. (a) Leeson, P. D.; Springthorpe, B. Nat. Rev. Drug Discov. 2007, 6, 881; (b) Leach, A. R.; Hann, M. M.; Burrows, J. N.; Griffen, E. J. Mol. BioSyst. 2006, 2, 429. 
Table 1. Structure-activity relationship of compounds 7-19<smiles>[R]c1cc(Cl)c(C2CC(=O)C(Sc3ccccc3Cl)=C(O)C2)c(Cl)c1[R]</smiles>

\begin{tabular}{|c|c|c|c|c|c|c|c|}
\hline $\begin{array}{c}\text { Compd. } \\
\text { No. }\end{array}$ & $\mathrm{R}^{1}$ & $\mathrm{R}^{2}$ & $\begin{array}{l}\text { LDHA IC }_{50} \\
(\mathrm{nM})\end{array}$ & $\begin{array}{c}\text { Compd. } \\
\text { No. }\end{array}$ & $\mathrm{R}^{1}$ & $\mathrm{R}^{2}$ & $\begin{array}{l}\text { LDHA IC }{ }_{50} \\
\quad(\mathrm{nM})\end{array}$ \\
\hline $6 b$ & $\mathrm{H}$ & $\mathrm{H}$ & 870 & 13 & & $\mathrm{H}$ & 60 \\
\hline 7 & & $\mathrm{H}$ & 240 & 14 & & $\mathrm{H}$ & 90 \\
\hline 8 & $\mathrm{H}$ & & 2,600 & 15 & & $\mathrm{H}$ & 100 \\
\hline 9 & & $\mathrm{H}$ & 230 & 16 & & $\mathrm{H}$ & 60 \\
\hline 10 & & $\mathrm{H}$ & 370 & 17 & & $\mathrm{H}$ & 108 \\
\hline 11 & & $\mathrm{H}$ & 100 & 18 & & $\mathrm{H}$ & 85 \\
\hline 12 & & $\mathrm{H}$ & 170 & 19 & & $\mathrm{H}$ & 1,100 \\
\hline
\end{tabular}

See ref.15 for experimental details associated with each assessment. LDHA biochemical inhibition results are reported as the average of 2 separate runs for compounds with $\mathrm{LDHA}^{\mathrm{IC}} \mathrm{C}_{50}<100 \mathrm{nM}$. For others, the result is from a single run. 
Table 2. Structure-activity relationship of compounds $\mathbf{2 0 - 3 2}$<smiles>[R]c1ccc(Cl)c(SC2=C(O)CC(c3c(Cl)cccc3Cl)CC2=O)c1</smiles>

\begin{tabular}{|c|c|c|c|c|c|}
\hline $\begin{array}{c}\text { Compd. } \\
\text { No. }\end{array}$ & $\mathrm{R}$ & $\begin{array}{l}\text { LDHA IC } C_{50} \\
(\mathrm{nM})\end{array}$ & $\begin{array}{c}\text { Compd. } \\
\text { No. }\end{array}$ & $\mathrm{R}$ & $\begin{array}{l}\mathrm{LDHA}_{\mathrm{IC}} \mathrm{C}_{50} \\
\quad(\mathrm{nM})\end{array}$ \\
\hline $6 b$ & $\mathrm{H}$ & 870 & 26 & $\mathrm{CH}_{2} \mathrm{CONMe}_{2}$ & 10,000 \\
\hline 20 & $\mathrm{OH}$ & 120 & 27 & $\mathrm{CH}_{2} \mathrm{CONHCH}{ }_{2} \mathrm{CH}_{2} \mathrm{OH}$ & 300 \\
\hline 21 & $\mathrm{OMe}$ & 370 & 28 & $\mathrm{CH}_{2} \mathrm{COOMe}$ & 40 \\
\hline 22 & $\mathrm{NH}_{2}$ & 640 & 29 & $\mathrm{CH}_{2} \mathrm{COOEt}$ & 130 \\
\hline 23 & $\mathrm{NHMe}$ & 170 & 30 & & 120 \\
\hline 24 & $\mathrm{CH}_{2} \mathrm{COOH}$ & 3,500 & 31 & & 6 \\
\hline 25 & $\mathrm{CH}_{2} \mathrm{CONHMe}$ & 1,800 & 32 & & 90 \\
\hline
\end{tabular}

See ref. 15 for experimental details associated with each assessment. Biochemical results as the arithmetic mean of at least 2 separate runs for compounds with LDHA $\mathrm{IC}_{50}<100 \mathrm{nM}$. Data for others is the result of a single run. 
Table 3. Structure-activity relationship of compounds 33-39<smiles>[R]c1ccc([R])c(SC2=C(O)CC(c3c(Cl)ccc([R1])c3Cl)CC2=O)c1</smiles>

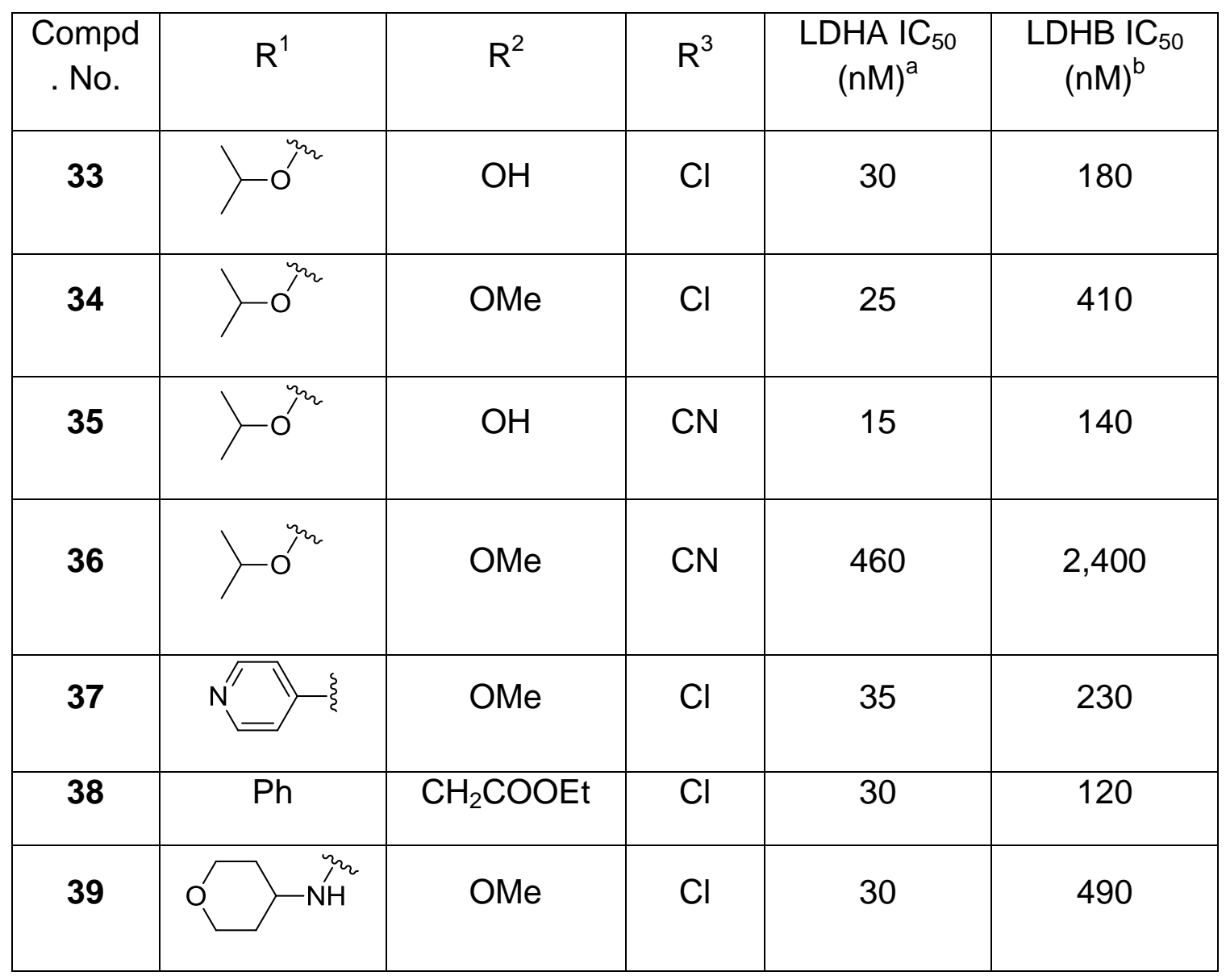

aLDHA biochemical inhibition results are reported as the arithmetic mean of 2 separate runs. ${ }^{b} \mathrm{LDHB}$ inhibition data are from a single run. 
Table 4. In vitro properties for representative examples

\begin{tabular}{|c|c|c|c|c|c|c|}
\hline $\begin{array}{c}\text { Compd. } \\
\text { No. }\end{array}$ & $\begin{array}{c}\text { HLM_Cl } \\
(\mathrm{ml} / \mathrm{min} / \mathrm{kg})\end{array}$ & $\begin{array}{c}\text { Human } \\
\text { PPB } \\
(\%)\end{array}$ & $\begin{array}{c}\text { MDCK } \mathrm{P}_{\text {app. } \mathrm{A}: \mathrm{B}} \\
\left(\times 10^{-6} \mathrm{~cm} / \mathrm{s}\right)\end{array}$ & $\begin{array}{c}\text { Kinetic } \\
\text { Solubility } \\
(\mu \mathrm{M})^{\mathrm{a}}\end{array}$ & cLogP & LLE $^{\mathrm{b}}$ \\
\hline $\mathbf{3 1}$ & 18 & $\mathrm{ND}^{\mathrm{c}}$ & 10.6 & 61 & 7.5 & 0.7 \\
\hline $\mathbf{3 5}$ & 19 & $>99.9$ & 1.1 & 50 & 5.0 & 2.8 \\
\hline $\mathbf{3 9}$ & 20 & $>99.9$ & 14 & 49 & 6.1 & 1.3 \\
\hline
\end{tabular}

${ }^{a}$ Kinetic solubility was measured at pH 7.4 in PBS buffer. ${ }^{b}$ See ref. $28 .{ }^{~}$ PPB could not be determined as mass peak $(\mathrm{M}+\mathrm{H})$ was not detected. 


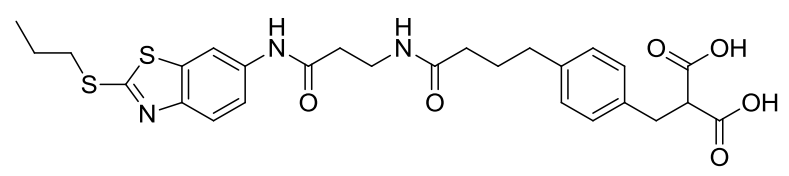

1

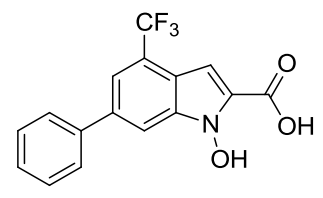

2

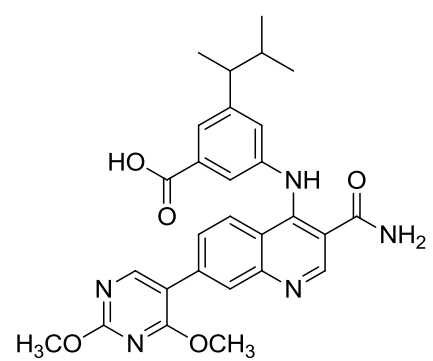

3

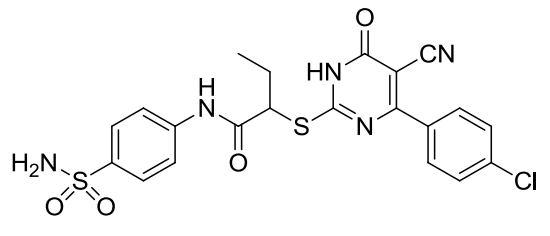

4

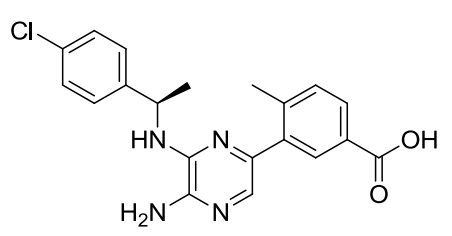

5

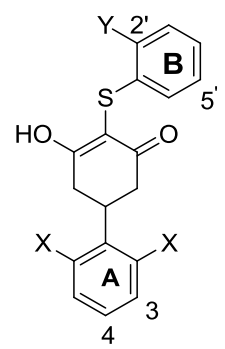

6a $\mathrm{X}=\mathrm{Br}, \mathrm{Y}=\mathrm{CN}$

6b $X=Y=C l$

Figure 1. Previously disclosed LDHA inhibitors. 
Figure 2

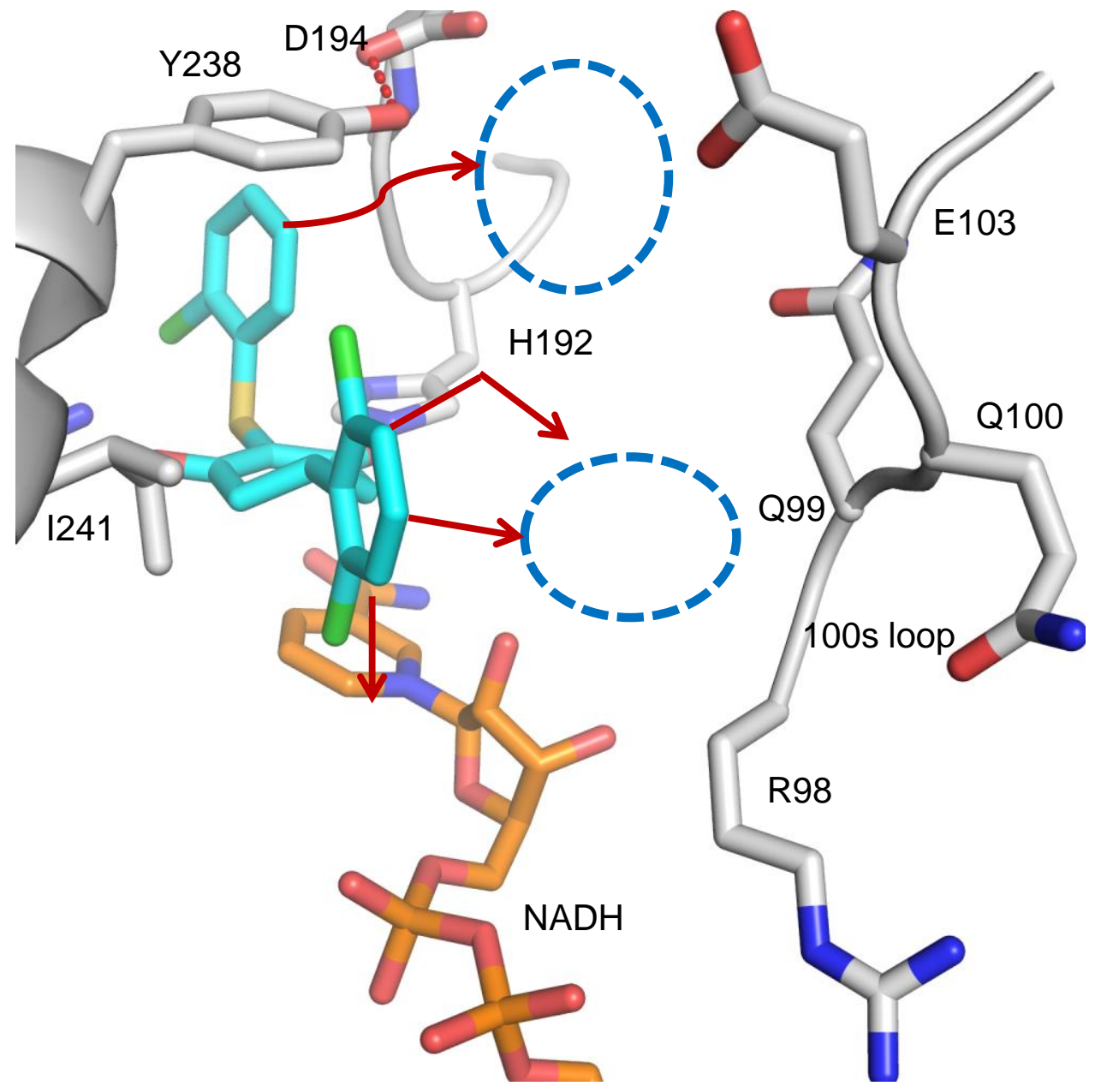


Figure $3 a$

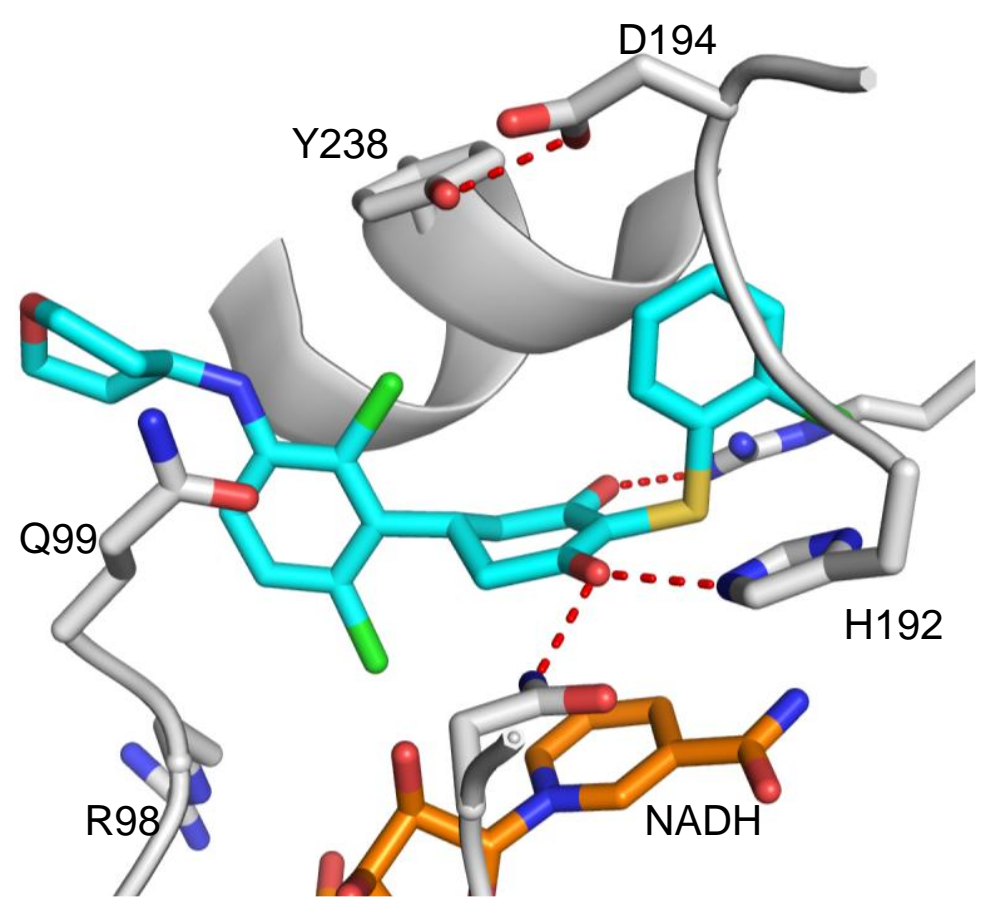

Figure $3 b$

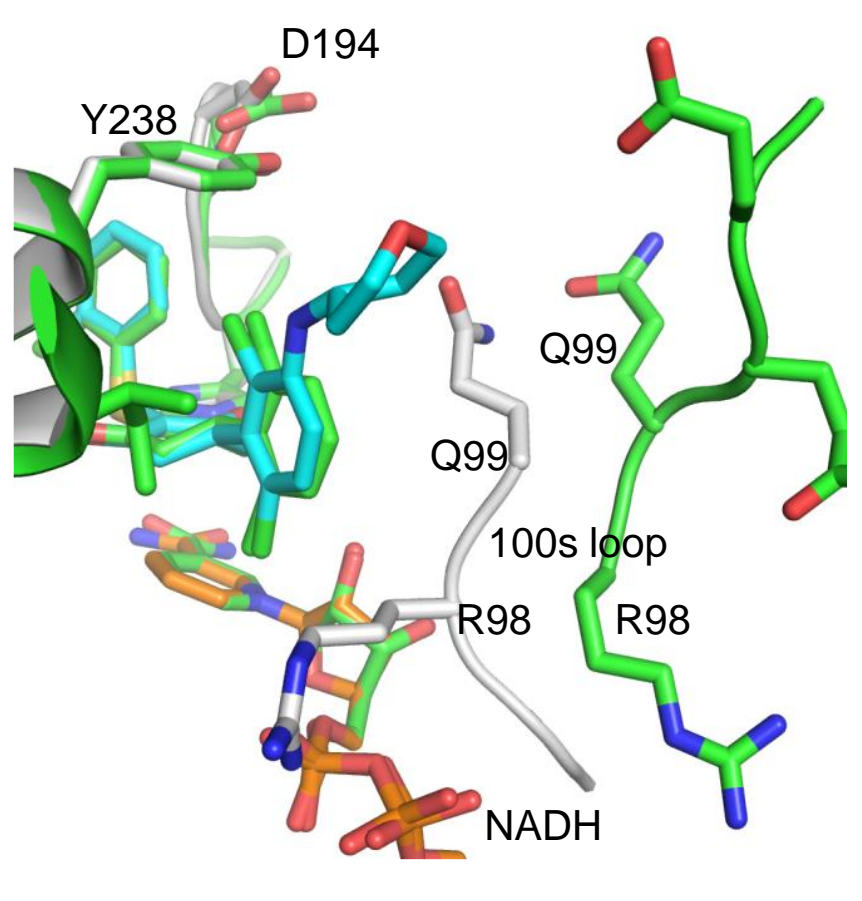


Figure 4

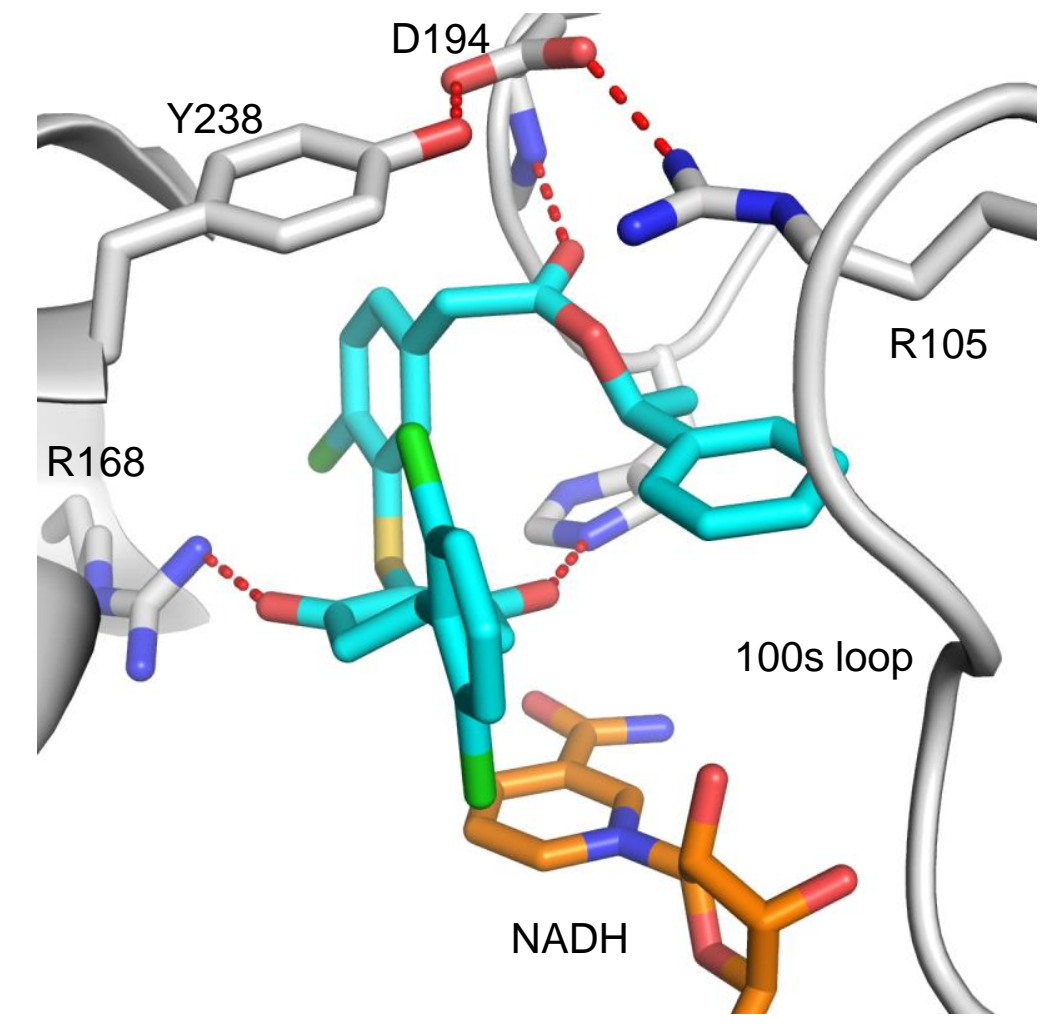


Figure 2. Depiction of the optimization strategy from the crystal structure of $\mathbf{6 b}$ (cyan) bound to LDHA (grey). Accessible space in the binding pocket is shown with blue ellipses. Red arrows indicate possible positions on ring $A$ and $B$ for functionalization.

Figure 3a. Co-crystal structure (3.2 $\mathrm{A}, \mathrm{PDB}$ code $=4 \mathrm{R} 69)$ of the inhibitor 13 (cyan) in complex with LDHA (grey). Hydrogen bonds are depicted as dashed red lines. Figure 3b. Overlay of co-crystal structures of inhibitor $\mathbf{1 3}$ (cyan) in complex with LDHA (grey) and inhibitor $\mathbf{6 b}$ (green) in complex with LDHA (green).

Figure 4. Co-crystal structure $(2.11 \AA$, PDB code = 4R68) of inhibitor 31 (cyan) in complex with LDHA (grey). Hydrogen bonds are depicted as dashed red lines. 
Scheme 1. Synthesis of compounds 7-19<smiles>[Y9][Y9][R]</smiles>

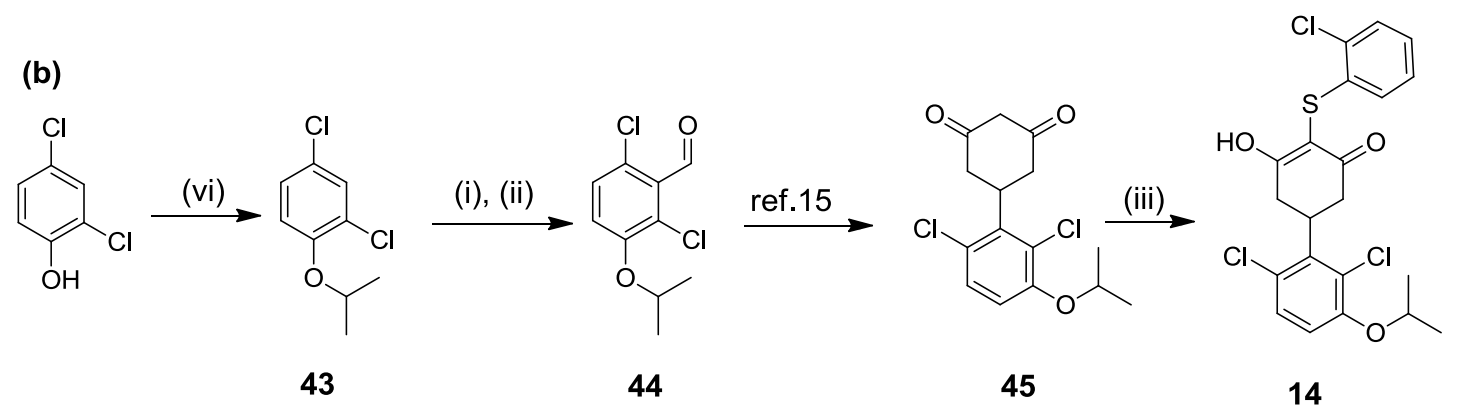<smiles>O=C1CC(c2c(Cl)cccc2Br)CC(O)=C1Sc1ccccc1Cl</smiles>

42

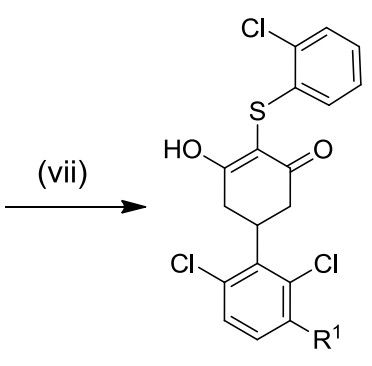

$15-19$

Reagents and reaction conditions: See Table 1 for $R^{1}$ substituents Scheme 1a: (i) LDA $2 \mathrm{M}$ in THF/heptane/diethylbenzene, $-78^{\circ} \mathrm{C}, 1 \mathrm{~h}$; (ii) DMF, $-78{ }^{\circ} \mathrm{C}, 2 \mathrm{~h}$; (iii) (2-CIPhS), $\mathrm{K}_{2} \mathrm{CO}_{3}, \mathrm{AcCN}, 80{ }^{\circ} \mathrm{C}, 2 \mathrm{~h}$; (iv) amine, $\mathrm{Cs}_{2} \mathrm{CO}_{3}, \mathrm{Pd}_{2}(\mathrm{dba})_{3}$, Xanthphos, toluene, $110{ }^{\circ} \mathrm{C}$, $16 \mathrm{~h}$; (v) $\mathrm{NaOH}$, water, $60^{\circ} \mathrm{C}$.

Scheme 1b: (i), (ii) and (iii) are the same as in Scheme 1a; (vi) 2-Bromopropane, $\mathrm{NaOH}, \mathrm{MeCN}, 80^{\circ} \mathrm{C}, 12 \mathrm{~h}$.

Scheme 1c: (vii) $\mathrm{R}^{1} \mathrm{~B}(\mathrm{OH})_{2}, \mathrm{Pd}\left(\mathrm{PPh}_{3}\right)_{4}, \mathrm{~K}_{2} \mathrm{CO}_{3}, 1,4$-dioxane, $6 \mathrm{~h}$. 
Scheme 2. Synthesis of compounds 20-32

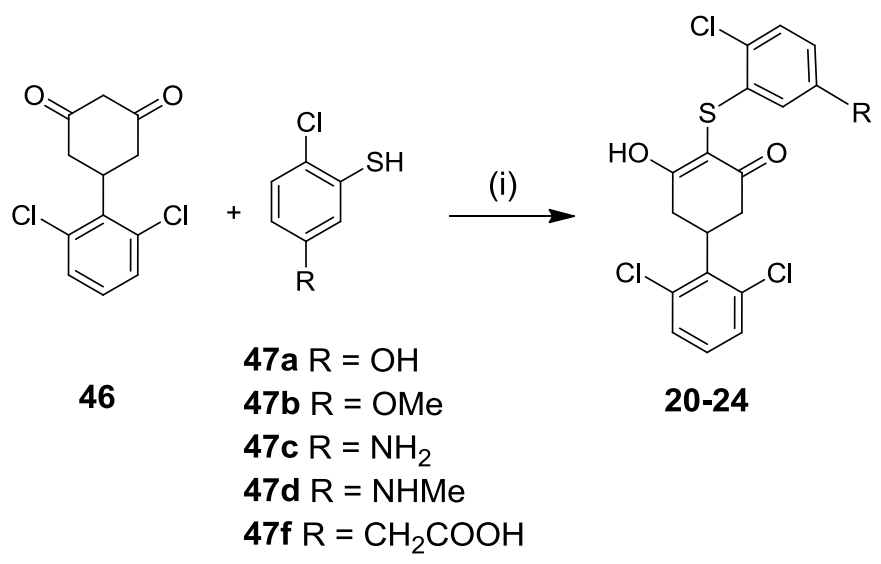

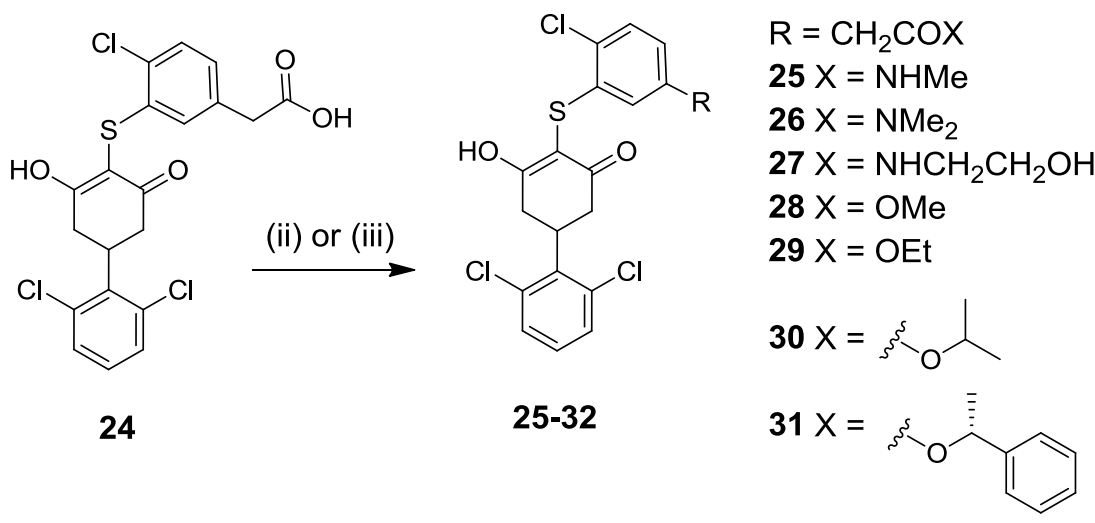<smiles>[Y20]=CCC(C)OC(C)c1ccccc1</smiles>

Reagents and reaction conditions: (i) $\mathrm{K}_{2} \mathrm{CO}_{3}$, acetonitrile, $80^{\circ} \mathrm{C}, 14 \mathrm{~h}$; (ii) amine, HATU, DIPEA, DMF, 16h; (iii) alcohol, $\mathrm{PPh}_{3}, \mathrm{DEAD}, \mathrm{Phl}(\mathrm{AcO})_{2}, \mathrm{THF}, \mathrm{RT}, 16 \mathrm{~h}$. 
Scheme 3. Synthesis of compounds 33-39

(a)<smiles>CC(C)Oc1ccc(Cl)c(C2CC(=O)CC(=O)C2)c1Cl</smiles>

45

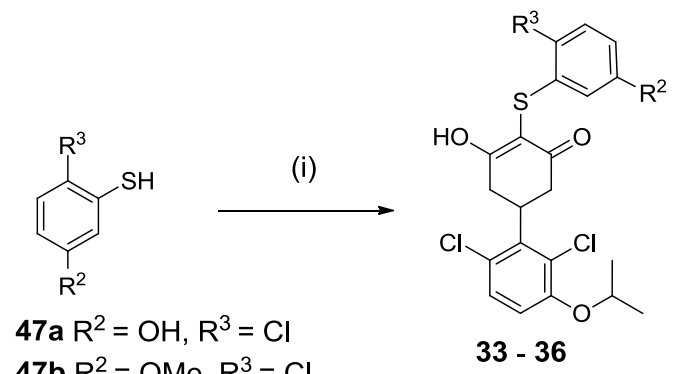

(b)

$47 \mathrm{R}^{2}=\mathrm{OH}, \mathrm{R}^{3}=\mathrm{CN}$

$47 \mathrm{~h} \mathrm{R}^{2}=\mathrm{OMe}, \mathrm{R}^{3}=\mathrm{CN}$<smiles>O=C1CC(=O)CC(c2c(Cl)ccc(Br)c2Cl)C1</smiles>

41 (ii)<smiles>[R]c1ccc(Cl)c(C2CC(=O)CC(=O)C2)c1Cl</smiles>

48

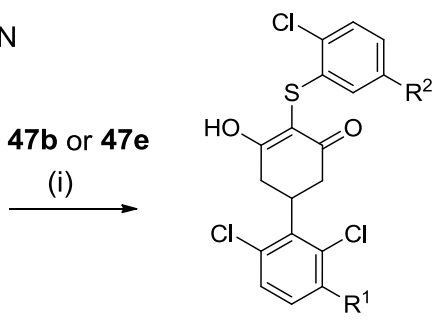

37, 38
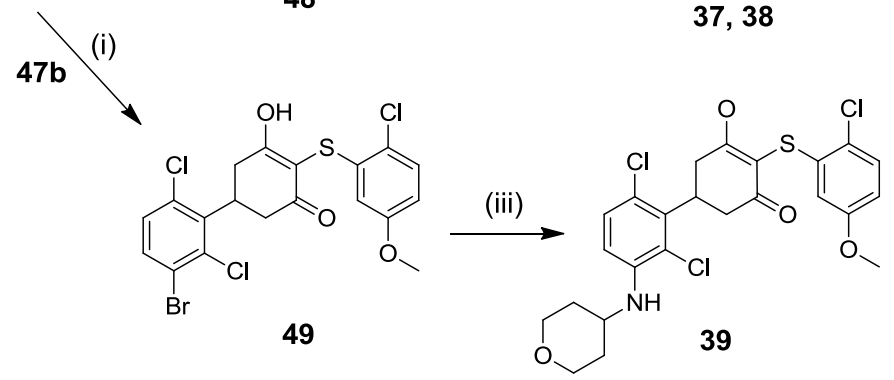

Reagents and reaction conditions: See Table 3 for $R^{1}$ and $R^{2}$ and $R^{3}$ substituents: (i) $\mathrm{K}_{2} \mathrm{CO}_{3}$, acetonitrile, $80^{\circ} \mathrm{C}, 14 \mathrm{~h}$ (ii) $\mathrm{R}^{1} \mathrm{~B}(\mathrm{OH})_{2}, \mathrm{Pd}(\mathrm{dppf}) \mathrm{Cl}_{2}, \mathrm{Cs}_{2} \mathrm{CO}_{3}, \mathrm{DMF}, 1 \mathrm{~h}, 110{ }^{\circ} \mathrm{C}$ microwave; (iii) 4-aminotetrahydropyran, $\mathrm{NaOt}$ - $\mathrm{Bu}, \mathrm{Pd}_{2}(\mathrm{dba})_{3}$, Brettphos, toluene, 110 ${ }^{\circ} \mathrm{C}, 12 \mathrm{~h}$. 